\title{
Solarcity i Gasometer Simmering: integralne kształtowanie środowiska mieszkaniowego - przykłady austriackie
}

\section{Solarcity and Gasometer Simmering: comprehensive shaping of urban residential environment - examples from Austria}

\begin{abstract}
Streszczenie
Współczesne trendy w rozwoju miast europejskich nierozerwalnie związane są z kształtowaniem polityki mieszkaniowej. Istotnym czynnikiem w tym działaniu jest świadomość władz lokalnych i obywateli dotycząca jakości miejsc zamieszkania i ich zrównoważonego rozwoju. Współpraca między władzami miasta, inwestorami oraz mieszkańcami może pozytywnie wpłynąć na podniesienie jakości przestrzeni, życia i funkcjonowania. Omawiane w artykule austriackie przykłady nowych obszarów mieszkaniowych pokazują, jak wielokierunkowo te działania są podejmowane, jak wiedeńska polityka mieszkaniowa funkcjonuje w odniesieniu do kształtowania przestrzeni publicznej miasta oraz jak realizacja Linz SolarCity wychodzi naprzeciw współczesnym rozważaniom na temat zrównoważonego rozwoju miast.
\end{abstract}

Słowa kluczowe: polityka mieszkaniowa, miasto, obszary mieszkaniowe

\begin{abstract}
Contemporary trends in development of European cities are firmly bound with shaping of housing policy. One important factor in these actions is the awareness of the local authorities and citizens with regard to quality of the settlements, as well as their sustainable development. Cooperation between the authorities, investors and residents could improve the quality of the space, as well as lives of its inhabitants. The examples of new residential areas in Austria, discussed in this article, prove in how many different directions such actions are taken; how housing policy of Vienna functions with regard to shaping of the public space and how the implementation of Linz SolarCity reaches out to contemporary discussion about sustainable growth of cities.
\end{abstract}

Keywords: housing policy, city, residential areas 


\section{WPROWADZENIE}

Według słownika ${ }^{1}$ integracja to słowo, które oznacza scalanie; proces tworzenia całości z części. Jak ten termin odnosi się do kształtowania nowoczesnych zrównoważonych miast, autorka postara się wyjaśnić w poniższym tekście.

Współcześnie problemy, które można zaobserwować, przyglądając się zmianom zachodzącym w przestrzeniach miejskich, w tym w obszarach mieszkaniowych, wynikają z braku dialogu pomiędzy ludźmi, którzy tę przestrzeń tworzą i są za nią odpowiedzialni: władze lokalne, inwestorzy, projektanci oraz użytkownicy. Często brakuje wspomnianej wcześniej integracji, czyli całościowego podejścia do planowania i projektowania, w tym synergii, która dawałaby większą szansę wielokierunkowego rozwoju miast i zapewniła zaspokojenie potrzeb ich mieszkańców. Zgodnie ze słowami Martina Berrego „(...) dobry projekt ma 5 twórców: polityków i inwestorów, projektantów, zaangażowaną społeczność i silnego przywódcę" ${ }^{\prime 2}$. Współpraca pomiędzy władzami miasta, inwestorami, specjalistami w dziedzinie projektowania a mieszkańcami daje nową wizję rozwoju miast, kreowania zrównoważonej przestrzeni miejskiej: przyjaznej i dostępnej dla wszystkich oraz kształtowania zdrowych i funkcjonalnych obszarów mieszkaniowych. Gospodarka przestrzenią i środowiskiem stała się przedmiotem działań większości rządów w Unii Europejskiej, za pośrednictwem specjalnie powołanych w tym celu ministerstw wiele krajów prowadzi własną politykę architektoniczną ${ }^{3}$. Dobrym odzwierciedleniem tych zsynchronizowanych działań są realizacje poprzemysłowych obszarów Gazometrów w Wiedniu oraz energooszczędna dzielnica SolarCity w Linzu. Pierwsza z nich jest doskonałym przykładem rewitalizacji terenów postindustrialnych na terenie miasta, zmiany jej funkcji przy jednoczesnym zapewnieniu miejsc pracy, mieszkań oraz zachowania ciągłości przestrzeni miejskiej. SolarCity to realizacja będąca wzorem zrównoważonego rozwoju obszarów miejskich, w skali zarówno lokalnej, jak i globalnej.

\section{GAZOMETRY SIMMERING, WIEDEŃ}

Rozwój mieszkalnictwa w Wiedniu zajmuje wyjątkową pozycję zarówno w teorii, jak i w praktyce. Prawie 60\% wiedeńskich gospodarstw domowych znajduje się w subwencjonowanych lokalach, a dwadzieścia tysięcy z nich to mieszkania socjalne. Dzięki refundacji miejskiej powstaje w Wiedniu od pięciu do siedmiu tysięcy mieszkań rocznie. To około 80-90\% wszystkich realizowanych lokali mieszkaniowych. Według polityki władz miejskich innowacyjna i przyjazna dla środowiska architektura powinna być dostępna dla wszystkich grup społecznych. Ten kompleksowy model socjalnej, zaplanowanej i zrównoważonej polityki kształtowania środowiska mieszkaniowego rozwija się w sposób ciągły, z zastosowaniem poszczególnych etapów planu, od końca pierwszej wojny światowej i jest współcześnie rozwijany w nadal trwającym procesie ${ }^{4}$. 
Już od lat 60. ubiegłego wieku Wiedeń koncentrował się na odnowie miasta. Podstawową zasadą oraz najważniejszym celem planów rozwoju miasta była gospodarka mieszkaniowa, rozumiana tu jako część dobra publicznego, połączona ze wspomnianym wcześniej systemem subwencjonowania. Programy rozwoju miasta STEP5 z 1984 i 1994 szczególną uwagę kierowały na odnowienie i podniesienie jakości życia w gęsto zabudowanych częściach miasta, jak również udoskonalenie ruchu komunikacyjnego w mieście oraz zachowanie dużych terenów zielonych ${ }^{6}$. W 2005 roku powstał kolejny program, obecnie wciąż realizowany w ramach STEP, który zakłada wielopłaszczyznowe działania, przekształcanie nieużytków miejskich na atrakcyjne obszary oraz rozwój zupełnie nowych terenów.

W wiedeńskiej dzielnicy poprzemysłowej Simmering znajdowały się ogromne pojemniki na paliwo, które od 1899 do 1986 roku zapewniały oświetlenie miasta7. Przez trzynaście lat po zamknięciu, do 1999 roku nie były w żaden sposób użytkowane. Cztery Gazometry dostały nowe życie w momencie, gdy władze Wiednia zaproponowały uznanym architektom zaadaptowanie ich w taki sposób, by ożywić całą poindustrialną strefę tej części miasta. Aby uzyskać taki efekt, postanowiono nie poprzestawać jedynie na realizacji funkcji mieszkaniowej, lecz stworzyć obszar miejski, w którym istnieć będą również przestrzenie użyteczności publicznej wraz z usługami towarzyszącymi.

Jednocześnie miasto chciało pozostać konsekwentne w swej polityce dotyczącej rozwoju obszarów zamieszkania. Stąd tkankę mieszkaniową Gazometrów tworzą lokale socjalne, mieszkania własnościowe i przeznaczone na wynajem ${ }^{8}$. Na tym jednak nie poprzestano. W „skorupie” ceglanych olbrzymów powstał także studencki akademik (il. 3), sala koncerto-

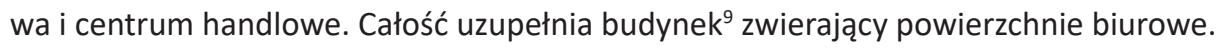

Gazometry zostały zaprojektowane przez różne zespoły projektowe. Do współpracy zaproszono znanych architektów, takich jak Jean Nouvel, Wolf D. Prix, Manfred Weldorn oraz Wilhelm Holzbauer. Każdy z architektów był odpowiedzialny za jeden obiekt, ale pracowano w zintegrowanym zespole, dzięki czemu ostateczna koncepcja stanowi spójną całość. W latach 1999-2001 trwały prace remontowo-budowlane, a od maja 2001 roku „Gasometer City” tętni nowym życiem. Wszystkie cztery obiekty to „małe miasta”, w których funkcje strefy publicznej zostały wprowadzone do wewnątrz i połączone z obszarem mieszkaniowym (il. 4).

\section{Gazometr A}

Autorem rewitalizacji tego obiektu, oznaczonego literą „A”, jest Jean Nouvel. W tym budynku fasady mieszkań zostały skierowane zarówno na zewnątrz, jak i do wewnątrz założenia, otwierając się na dziedziniec umieszczony w środku. Tutaj znajduje się także centrum handlowe, którego przeszklona kopuła jest jednocześnie transparentną „podłogą” dla otwartego wnętrza położonej powyżej części mieszkalnej ${ }^{10}$. Ta ogromna luksfera daje światło w części usługowej (il. 5), tworząc również pewien szczególny rodzaj granicy pomiędzy przestrzenią publiczną a półpubliczną. 


\section{Gazometr B}

Obiekt „B" projektu pracowni CoopHimmelb(I)au wyróżnia się przystawionym od zewnątrz „złamanym” w pionie blokiem, w którym znajdują się powierzchnie biurowe. Gazometr ten jest też częściowo zaadaptowany na potrzeby studentów, natomiast w przyziemiu zlokalizowano halę wielofunkcyjną przystosowaną do organizacji imprez masowych ${ }^{11}$.

\section{Gazometr C}

Głównym złożeniem Manfreda Wehdrona, czyli architekta odpowiedzialnego za adaptację trzeciego omawianego budynku Gazometru C, było podejście ekologiczne. Historyczna kopuła została zachowana w formie „szkieletu konstrukcyjnego”, a na balkonach, powstałych dzięki tarasowej formie architektury, założono ogrody obsadzane drzewami i krzewami. Tu mieszkańcy mają możliwość korzystania z zieleni na wyłączność, a dzięki uskokowemu stopniowaniu kolejnych kondygnacji, wewnętrzy dziedziniec jest lepiej doświetlony.

\section{Gazometr D}

Ten budynek, zaprojektowany przez Wilhelma Holzbauera, dostał całkiem nowe wnętrze, ukryte w historycznej skorupie. W plan koła wstawiony został trzyramienny wieżowiec, dzięki czemu każde z mieszkań zwrócone jest w stronę wewnętrznych dziedzińców. Dolne kondygnacje przeznaczono na archiwa miejskie oraz państwowe.

Na terenach sąsiadujących z układem czterech Gazometrów znajduje się obszar mieszkaniowy zrealizowany zgodnie z zasadami architektury pasywnej - Villa Verdi; Kino Zentrum „Hollywood MegaplexGasometer” kompleks kinowy wraz z centrum rozrywki oraz stacja metra, której obecność zaznacza wielki zawór gazu².

Gazometry miały stać się sercem tej postindustrialnej części Wiednia, zbudować „miejskość" zarówno wewnątrz samych budynków, jak i w otaczającym je obszarze. Ich rewitalizacja zwiększyła zainteresowanie inwestorów tą dzielnicą. Stąd powstanie założenia Villa Verdi - niewielkiego osiedla mieszkaniowego, które architekt, Albert Wimmer, zaprojektował oraz zrealizował zgodnie z zasadami budownictwa pasywnego, tak by utrzymać w tej części miasta równowagę ekologiczną. Chciał stworzyć obszar korespondujący z Gazometrami, ich kulturową i historyczną wartością. Rezultatem tego pomysłu są „wille miejskie”"13, które wpisują się w obszar zrewitalizowanego okręgu Simmering, tworząc w nim zielony akcent. Kolejnym krokiem do ożywienia i zbudowania „miejskości” obszaru było stworzenie (od strony północnej Gazometrów) Centrum Rozrywki z salami kinowymi, kasynem oraz przestrzeniami rekreacyjnymi.

Jak wynika z opinii dotyczącej obszaru, zaproponowany program ogólnomiejski jest zbyt rozbudowany. Sąsiednie obszary powinny zostać doinwestowane funkcją mieszkaniową, aby zwiększyć liczbę użytkowników. 


\section{3. „SOLARCITY” PISCHLING, LINZ}

Wpisując się w ogólnoświatowe tendencje, władze miasta Linz w 1991 roku uzgodniły program mieszkaniowy dla obszaru Pischling, skupiając się na rozwoju niskoenergetycznego budownictwa. Zdecydowano się na wybór regionu charakteryzującego się dużą dostępnością komunikacyjną, zabudową jednorodzinną oraz niewielkim jeziorem i bagnami Traun-Dunaj, znajdującymi się na największym ciągu naturalnych krajobrazów w Górnej Austrii ${ }^{14}$.

Plan cieszył się ogromnym zainteresowaniem wspólnot mieszkaniowych oraz firm budowlanych. W związku z tym władze miasta postanowiły podnieść prestiż przedsięwzięcia, zapraszając do współpracy przy realizacji obszaru mieszkaniowego światowej sławy architektów oraz ekspertów specjalizujących się w systemach budownictwa pasywnego.

Plan zagospodarowania dzielnicy SolarCity obejmuje rozwój obszarów miejskich dla około pięciu tysięcy mieszkańców oraz powiązanie go z istniejącym krajobrazem. Wykonanie koncepcji urbanistycznej zlecono austriackiemu profesorowi Ronaldowi Reinerowi. Realizacja ta to przykład pasmowego rozwoju z nanizaniem jednostek mieszkaniowych na ciąg szybkiej komunikacji szynowej. Jedną z takich jednostek jest zrealizowane osiedle będące manifestacją idei niskoenergetycznego budownictwa, poprzez wykorzystanie rozwiązań architektonicznych wspierających redukcję poboru energii.

Zabudowa SolarCity powstawała w kilku etapach, a architektami, którzy brali udział w tym przedsięwzięciu, byli: Norman Foster, Richard Rogers, Thomas Herzog, Norbert Kaiser (Grupa READ, Renewable Energies in Architecture and Design ${ }^{15}$, utworzona na potrzeby realizacji założenia) oraz Martin Treberspurg. Wszystkie projekty prowadzone były przy współudziale rady doradczej, reprezentowanej przez sektor publiczny, biznesowy i społeczność lokalną ${ }^{16}$.

Zaprojektowaniem otwartych terenów rekreacyjnych (il. 7) zajęła się grupa architektów krajobrazu z Atelier Dreiseit|l ${ }^{17}$. To za ich sprawą miejscowy krajobraz został odrestaurowany, a dzięki zachowaniu zieleni i mokradeł powstała sieć siedlisk. Użyteczność terenów zielonych (które należą do obszaru „Natura 2000”) oraz rekreacyjnych wspiera park i jezioro Weikersee ${ }^{18}$.

Obszar działań władz miejskich nie sprowadza się tylko do monitorowania poszczególnych etapów realizacji. W ramach programu badań w zakresie technologii dla zrównoważonego rozwoju zainicjowanego przez Federalne Ministerstwo Transportu, Innowacji i Technologii, w podprogramie „Building of Tomorrow” („Budowanie Przyszłości”), miasto Linz opracowato metodę oceny rozwoju obszarów miejskich w ramach programu „LES - Linz rozwinięte miasto!". Zawiera ona szereg kryteriów dla zrównoważonego rozwoju obszarów miejskich i używana jest do oceny dużych projektów budowlanych. Wykaz kryteriów obejmuje:

- podsumowanie ogólnych wymagań dotyczących zrównoważonego rozwoju obszarów miejskich,

- aspekty społeczne,

- aspekty odnoszące się do kwestii dotyczących poboru energii oraz ochrony środowiska, w tym związanych z czynnikami ekonomicznymi. 
Dzięki bazie danych dostępnej w sieci internetowej, katalog z wytycznymi jest łatwo dostępny dla pracowników administracyjnych miasta i obywateli ${ }^{19}$.

W 2007 roku władze miasta przeprowadziły kolejną ewaluację przedsięwzięcia, tym razem za pomocą programu BMVIT „Rozwój zrównoważony” i wykorzystanego już wcześniej podprogramu „Building of Tomorrow”. Badania miały na celu zebranie dokumentacji dotyczącej jakości projektu SolarCity w zakresie ochrony klimatu, poziomu zadowolenia mieszkańców oraz wyników dotyczących energooszczędności. Wykazano, że „(...) potwierdza (się) istnienie praktycznej możliwości osiągnięcia zrównoważonego rozwoju obszarów miejskich nawet w bezpośrednim sąsiedztwie chronionych siedlisk przyrodniczych"20.

Na układ urbanistyczny założenia składa się zabudowa podzielona na cztery kwartały z centralnie położonym placem miejskim - Luna Platz. Przestrzeń placu zaprojektowana została przez Auer+WeberArchitekturbuero+Partner i skupia wokół siebie ofertę handlową, edukacyjną, kulturotwórczą (biblioteka) oraz komunikacyjną (przystanek szybkiego tramwaju). Teren ten jest łatwo dostępny i można się do niego dostać pieszo, z każdej części obszaru.

W wyposażeniu centrum oraz uliczek doprowadzających użytkowników do środka założenia znalazły się kolorowe wiaty mające dawać cień podczas upalnych dni, a w trakcie tych deszczowych schronienie (il. 8). Jednak plac sprawia wrażenie opustoszałego, jest bardziej przystankiem komunikacji miejskiej niż miejscem spotkań.

Forma architektury otrzymała różne oblicza, jednak każde z nich zostało zaprojektowane zgodnie z zasadami budownictwa pasywnego. Budynki już na pierwszy rzut oka odróżniają się od siebie: ukształtowaniem brył (od prostych, po bardziej złożone) oraz długością poszczególnych pasm. Co za tym idzie; różnią się układem stref sąsiedzkich (półprywatnych) oraz dostępem do nich, dzięki czemu w całym założeniu łatwo zauważalny jest podział funkcjonalny przestrzeni.

Obszar projektowany przez Richard Rogers Partnership (strona północna sąsiadująca z terenami zielonymi/rekreacyjnymi) to budynki o dwóch kondygnacjach w formie długich bloków. Tu zieleń oraz ciągi piesze, w założeniu, miały wydzielać strefy prywatne. O tym, że pomysł segregacji, za pomocą samej roślinności, się nie sprawdził, świadczy dobitne zaznaczanie granic za pomocą ogrodzeń. Jednostki mieszkalne są tu drobno-gabarytowe, co tworzy układ przypominający tereny zabudowy jednorodzinnej.

W obszarach zabudowy o większych gabarytach również przewidziano rozszerzenie strefy prywatnej o przydomowe ogródki, przy mieszkaniach znajdujących się na parterze. I tutaj zieleń odgrywa niebagatelną rolę, izolującą mieszkańców przed przypadkowymi obserwatorami. Skwery z trawnikami, krzewami, placami zabaw, a nawet stolikami i krzesełkami, to obszary, które integrują mieszkańców i dają szansę na zawiązywanie więzi sąsiedzkich. Mocno zauważalne jest też, że przestrzenie przeznaczone są tylko na użytek mieszkańców okolicznej zabudowy.

W kwartale, gdzie znajdują się budynki galeriowe autorstwa Herzog \& Partner, układ urbanistyczny jest dużo luźniejszy. Powoduje to, że przestrzenie między nimi są większe, przez 
co nie tworzą wnętrz. Znajdują się wśród zieleni, jednak brak wydzielonych stref dostępnych jedynie dla mieszkańców (poza strefą prywatną ogrodów w parterach) sprawia wrażenie mniej przyjazne stałym użytkownikom.

Na obrzeża układu trafiły funkcje towarzyszące dzielnicom mieszkaniowym, takie jak: szkoła, przedszkole oraz otwarte tereny zielone. Do szkoły BRG SolarCity (il. 9, 10) można się dostać pieszo, a dojście zostało zrealizowane w sposób bezkolizyjny i nie przecina żadnej z dróg komunikacji kołowej. Inaczej jest z przedszkolem Kindergarten Weikerlseestrasse, gdzie zaplanowano możliwość dojazdu samochodem, jednak pozostawiając układ komunikacyjny bezpieczny i przyjazny pieszym.

Tereny rekreacyjne osiedla są buforem pomiędzy dzielnicą mieszkaniową SolarCity a pasami zieleni i mokradeł przynależnych do Doliny Traum Dunaj-Augen, należących do, wspomnianych już wcześniej, chronionych obszarów „Natura 2000”21. Strefa ta została zaprojektowana przez Atelier Dreiseit| ${ }^{22}$, które specjalizuje się w kształtowaniu architektury krajobrazu. Innowacyjna koncepcja projektowa tych terenów zakładała powstanie atrakcyjnie urządzonych przestrzeni wypoczynkowych na terenie miejskim, w tym nowej plaży oraz jeziora, wykorzystanie naturalnie występujących różnic terenów, wkomponowanie w nie elementów rekreacyjnych ${ }^{23}$.

W rezultacie powstał bardzo ciekawie rozwiązany obszar, dający możliwość relaksu, kreatywnych zabaw, z możliwością uprawiania sportów. Dodatkowo, na pozytywny odbiór przestrzeni wpływa fakt jej powiązania z obszarem naturalnej zieleni, co daje mieszkańcom możliwość kontaktu z przyrodą niewystępującą w mieście, bez pokonywania dużych odległości.

\section{PODSUMOWANIE}

Najistotniejszym elementem w planowaniu miasta XXI wieku jest człowiek, dlatego strategia rozwoju przestrzeni mieszkaniowych i publicznych przyjęta w Wiedniu opiera się na zapewnieniu aktywności ludzi oraz „ruchu”. Na podstawie wizji, kim będą użytkownicy, powstaje przestrzeń do nich dopasowana, a ostatnim elementem w kształtowaniu przestrzeni publicznej są budynki. Wynika to z przyjętego założenia, że dopiero wzajemne przenikanie się przestrzeni publicznej z budynkami daje pełen efekt.

Studia powyższych realizacji pokazują, jak istotną rolę ma zintegrowana współpraca pomiędzy władzami administracyjnymi miasta, inwestorami, planistami oraz mieszkańcami włączonymi w proces projektowania. Aktywne współdziałanie wszystkich stron, nie tylko na etapie realizacji inwestycji, lecz bieżące monitorowanie jej funkcjonowania poprzez ewaluację, jest kluczowe dla rozwoju oraz kształtowania współczesnych miast oszczędnych i zrównoważonych.

W obu omawianych realizacjach widać, jak duży nacisk położony jest na kształtowanie zdrowego miasta poprzez tworzenie atrakcyjnych dla użytkowników przestrzeni publicznych 
i sąsiedzkich oraz zapewnienie kontaktu z zielenią. Na władzy publicznej i podmiotach gospodarczych spoczywa obowiązek wprowadzania do planów i projektów rozwiązań ekologicznych, które mogą zapewnić zrównoważony rozwój obszarów miejskich. Analizowane przykłady austriackich realizacji pokazują, jak dzięki zintegrowanym działaniom administracyjnym, planistycznym oraz społecznym można stworzyć system miejskich przestrzeni publicznych o wysokiej jakości. Wiedeńskie Gazometry są ilustracją nowoczesnego kształtowania stref ogólnodostępnych, które towarzyszą zabytkowej formie architektury przy jednoczesnym zachowaniu charakteru wielkomiejskości w obszarach zabudowanych. SolarCity natomiast to modelowy przykład ekologicznego rozwoju w postaci jednostek mieszkaniowych o ograniczonej wielkości wnikających w istniejące środowisko naturalne.

W polskich miastach wciąż zauważalny jest brak instrumentów partycypacyjnych oraz planistycznych pozwalających na właściwe kształtowanie przestrzeni publicznej oraz rekreacyjnej, która decyduje o charakterze miejsca, stanowi strefę spędzania wolnego czasu, rozrywki, pełni funkcję wspólnototwórczą. To tam koncentrują się aktywności życia miejskiego, dochodzi do wymiany poglądów ${ }^{24}$. Wymienione czynniki przyczyniają się do kształtowania lokalnej tożsamości. Przestrzeni publicznych oraz zielonych w polskich obszarach mieszkaniowych jest zbyt mało, by mogły stać się atrakcyjnymi miejscami spotkań i spędzania czasu.

W podsumowaniu raportu Przestrzeń życia Polaków Janusz Sepioł pisze:

„Potrzebujemy racjonalnej polityki miejskiej i nowej, aktywniejszej polityki mieszkaniowej. Samo zestawienie liczby mieszkań na tysiąc mieszkańców w Polsce i w krajach, które stanowią dla nas punkt odniesienia, pokazuje, jak wiele jeszcze terenów musimy poddać urbanizacji i jak duża pula inwestycji jest jeszcze przed nami. Z jednej strony to wyzwanie, z drugiej zaś szansa, że pojawi się ta nowa substancja, ta nowa masa krytyczna, która potrafi zmienić, poprawić obraz kraju. Osiągniemy sukces, jeśli te działania „od góry” spotkają się z ruchem „od dołu”. Z ruchem generowanym troską i ambicją właścicieli nieruchomości, członków lokalnych społeczności, wreszcie wspólnot samorządowych o jakość domów, ogrodów, zieleni przyulicznej, stanów placów i ulic, ścieżek rowerowych, terenów rekreacyjnych, parków, alei, całej zieleni publicznej. Tę troskę i ambicję można skutecznie mobilizować zachętami podatkowymi, małymi grantami, a także dobrą promocją"25.

Cytat ten dobitnie pokazuje, że synergiczne działania fachowców w dziedzinie projektowania, administracji, inwestorów oraz społeczności lokalnych mogą stać się drogą do sukcesu w kształtowaniu zrównoważonego miasta, w którym przestrzenie publiczne, obszary mieszkaniowe oraz zieleń stanowią zintegrowaną strefę do użytkowania i życia mieszkańców. 


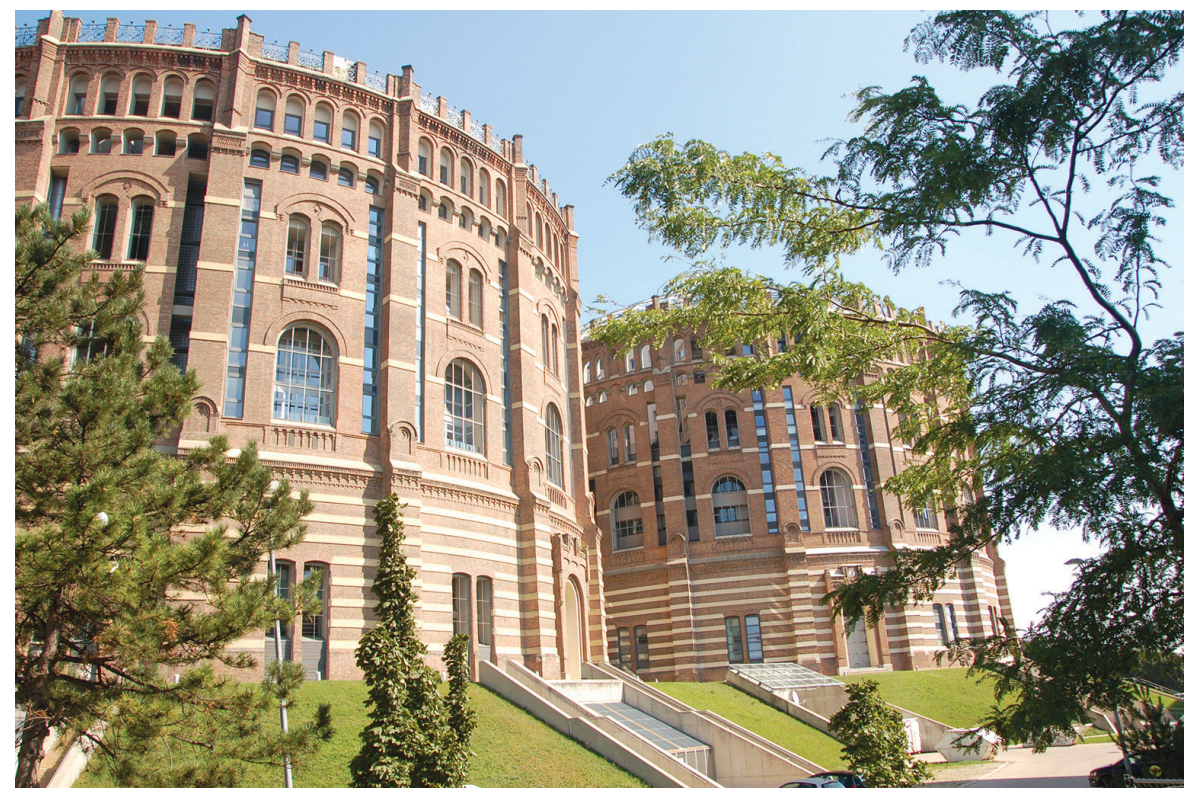

II. 1. Wiedeń, Gazometry C i D (fot. M. Bednarz) III. 1. Vienna, Gasometers C and D

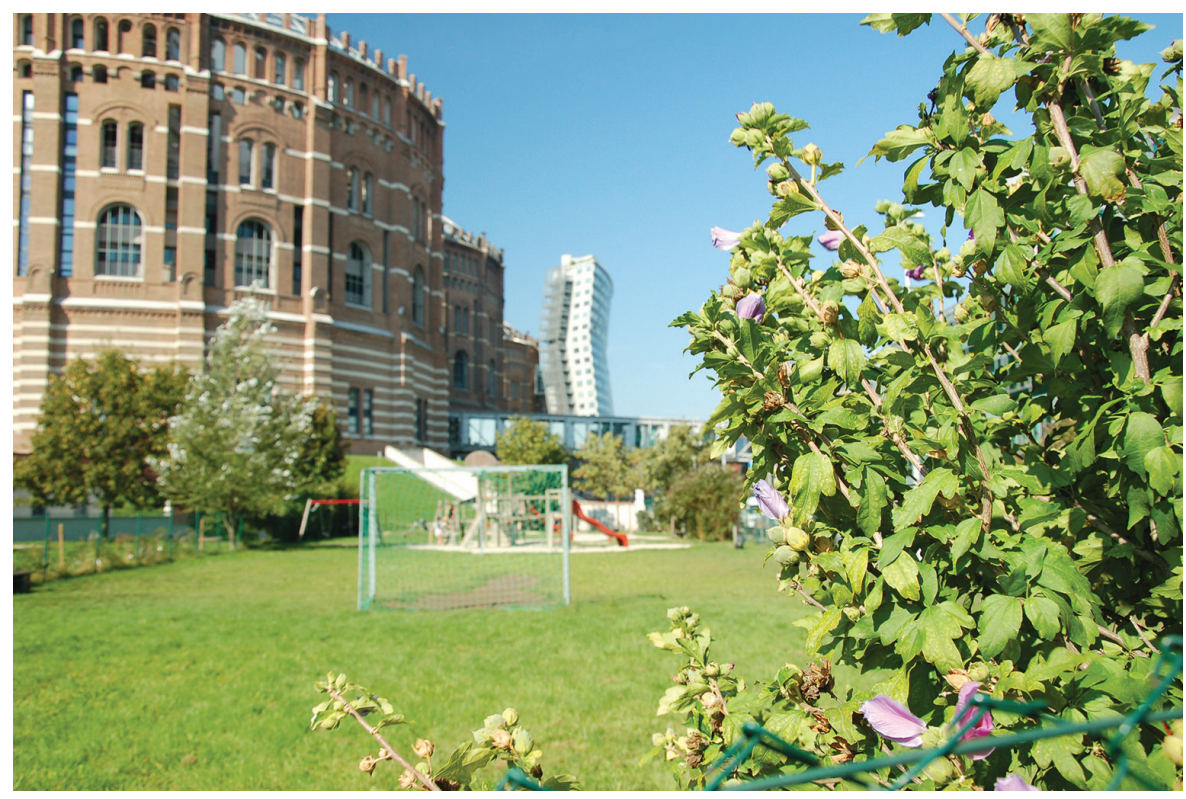

II. 2. Wiedeń, Gazometry, widok na plac zabaw (fot. M. Bednarz) III. 2. Vienna, Gasometers, view on the playground 


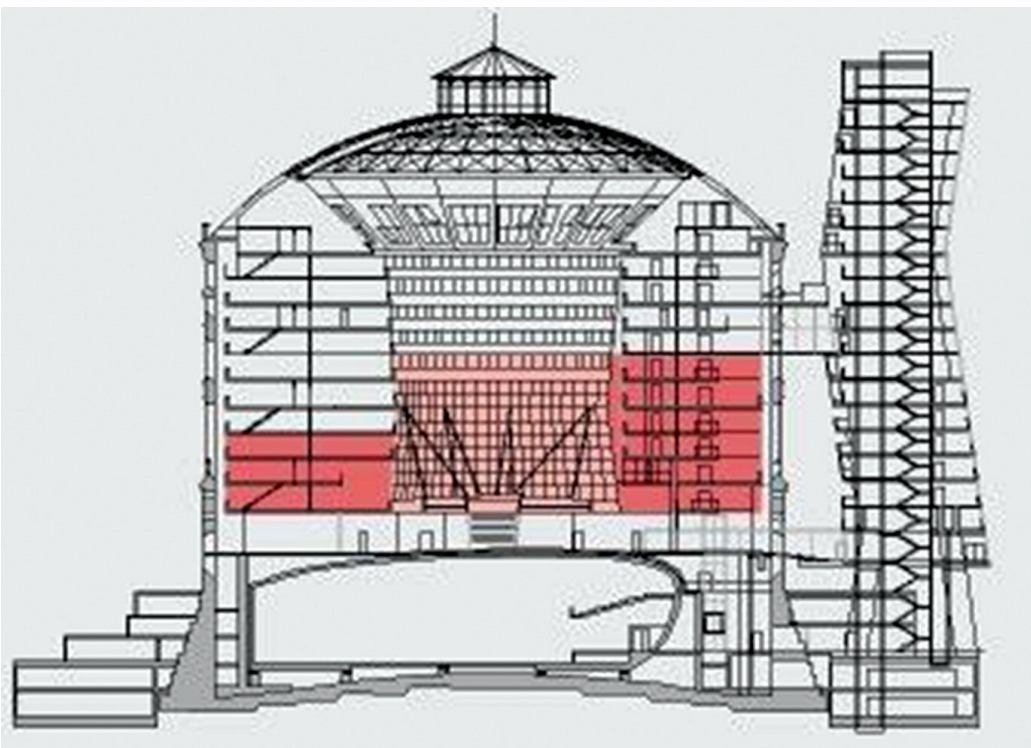

II. 3. Wiedeń, Gazometr B, mieszkania dla studentów (źródło: http://www.wbv-gpa.at)

III. 3. Vienna, Gasometer B, students apartments

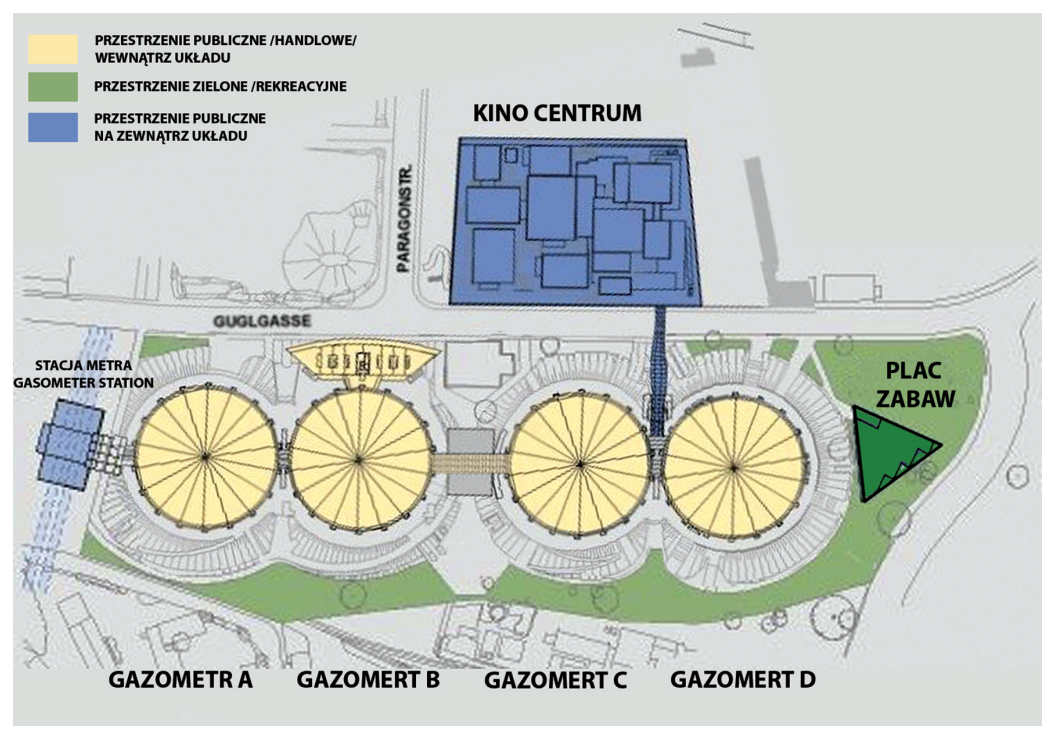

II. 4. Wiedeń, Gazometry, Analiza planu sytuacyjnego przestrzeni Gazometrów, podział ze względu na funkcję (opr. M. Bednarz, na podst. źródła: http://www.wbv-gpa.at)

III. 4. Vienna, Gasometers, Situation plan with space analysis, functional division 


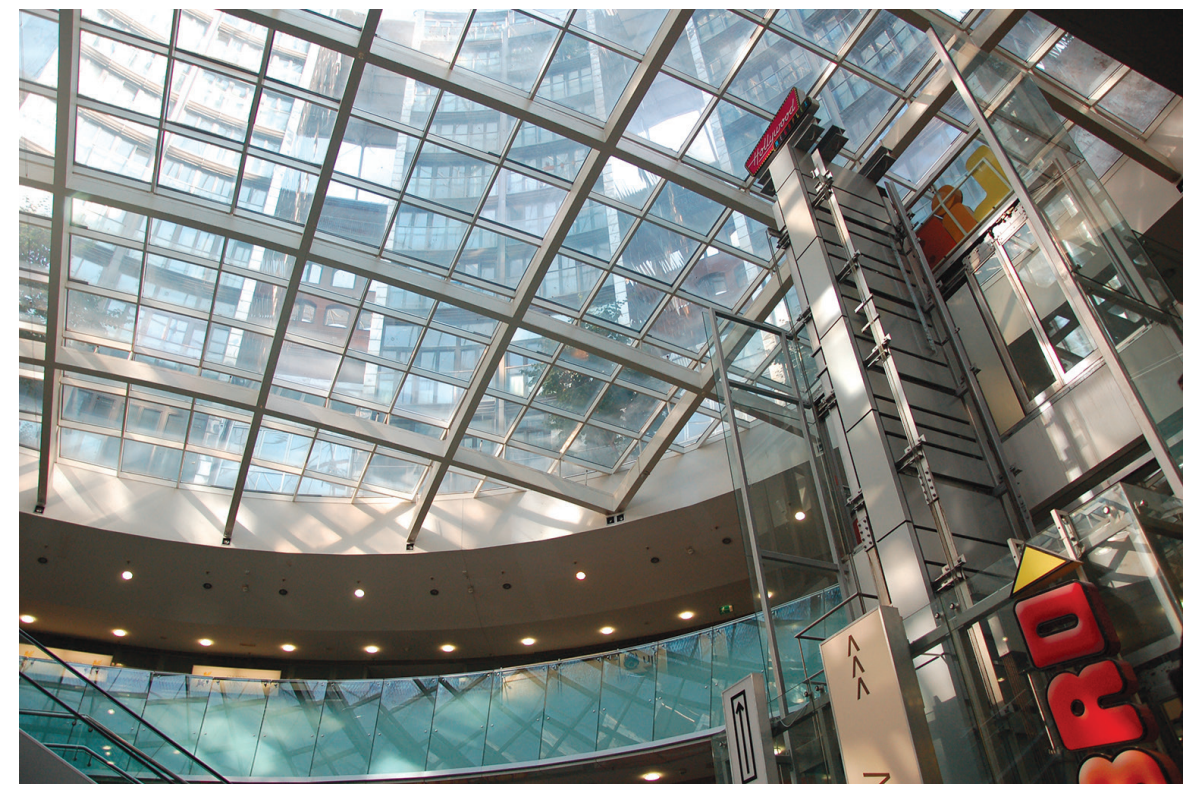

II. 5. Wiedeń, Gazometr A, wnętrze Centrum Handlowego (fot. M. Bednarz) III. 5. Vienna, Gasometer A, Mall

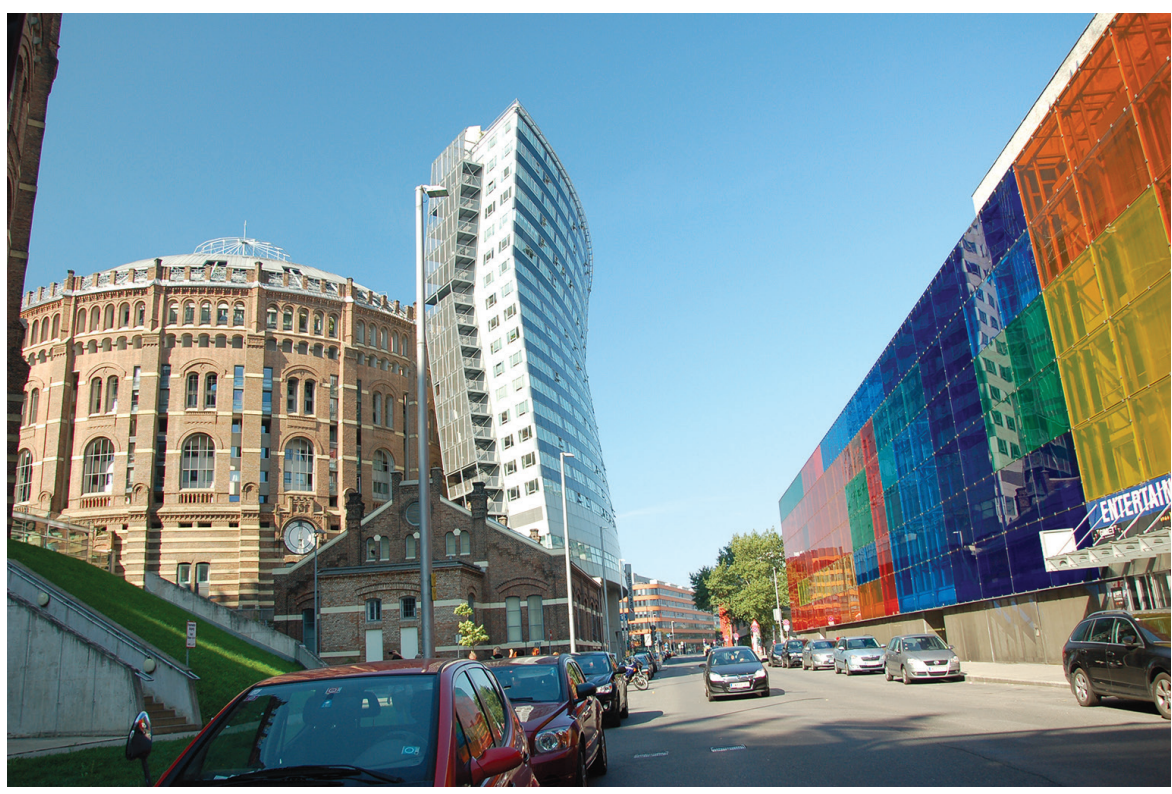

II. 6. Wiedeń, Gazometr B oraz przestrzeń ulicy Guglgasse (fot. M. Bednarz) III. 6. Vienna, Gasometer B, Guglgasse street 


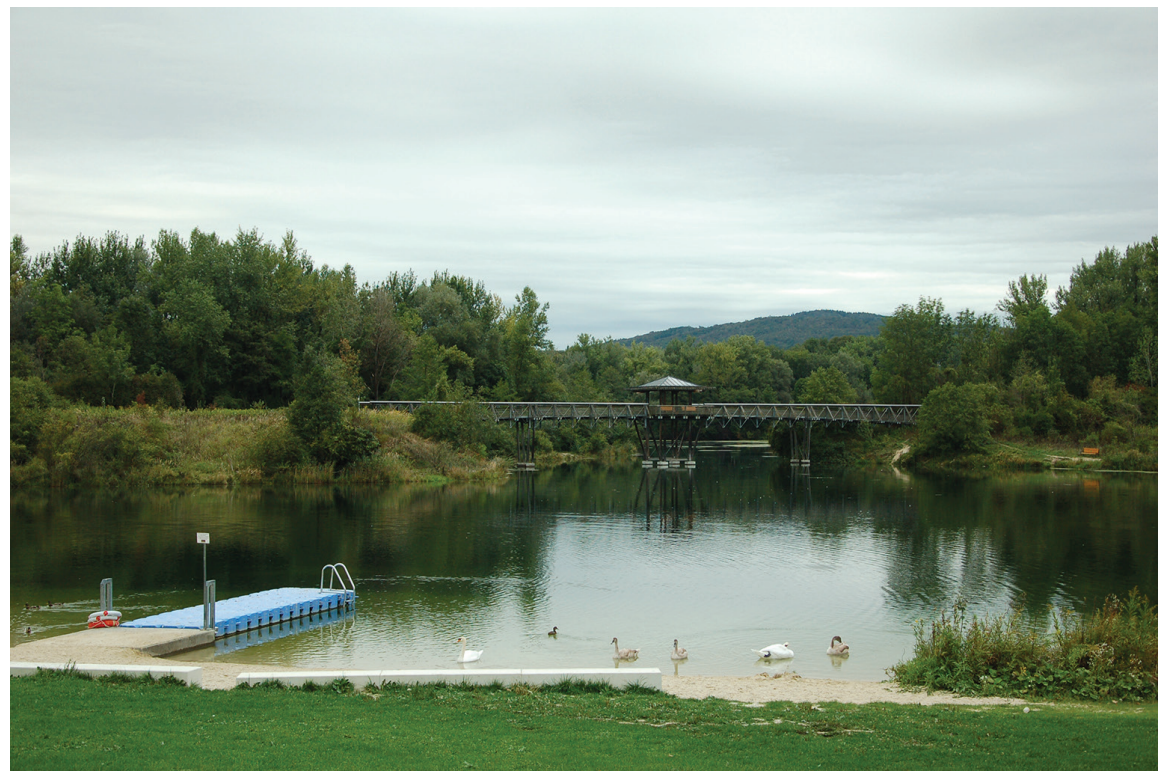

II. 7. Linz, SolarCity, Tereny rekreacyjne, okolice jeziora Weikersee (fot. M. Bednarz) III. 7. Linz, SolarCity, Recreational and Weikersee lake areas

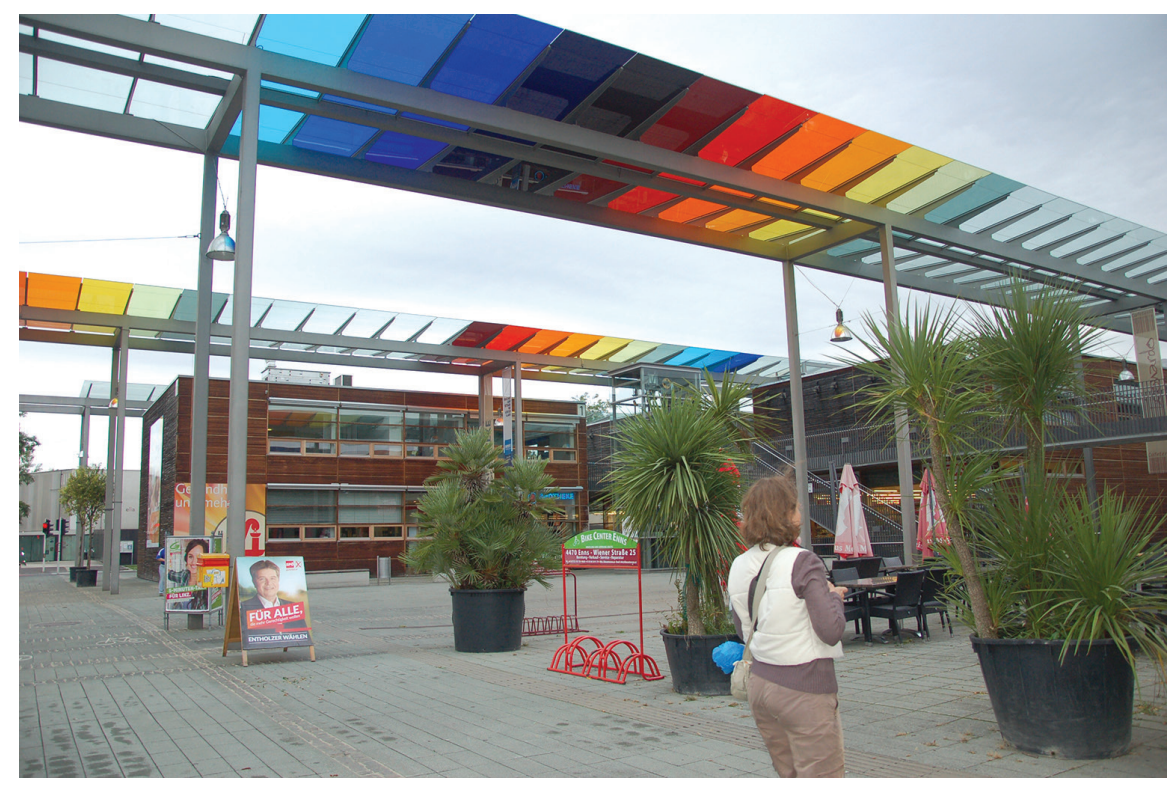

II. 8. Linz, SolarCity, LunaPlatz (fot. M. Bednarz)

III. 8. Linz, SolarCity, LunaPlatz 


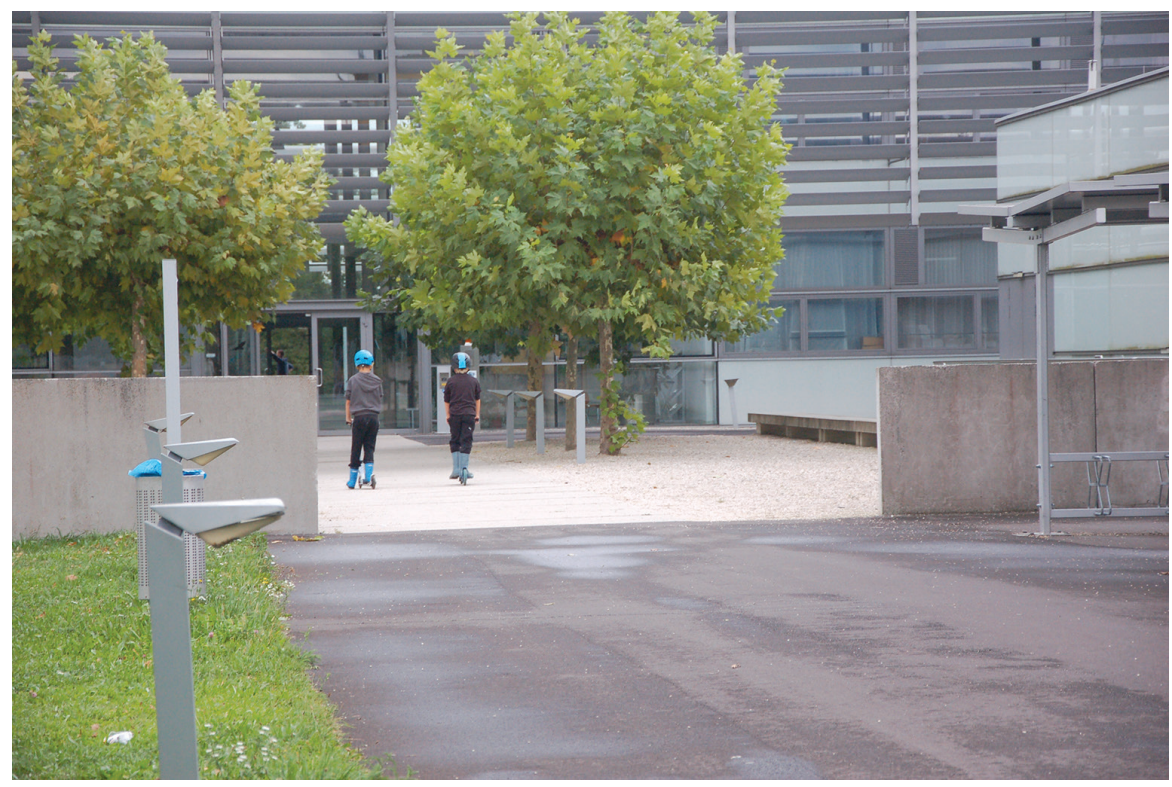

II. 9. Linz, SolarCity, Szkoła BRG SolarCity (fot. M. Bednarz) III. 9. Linz, SolarCity, BRG SolarCity School

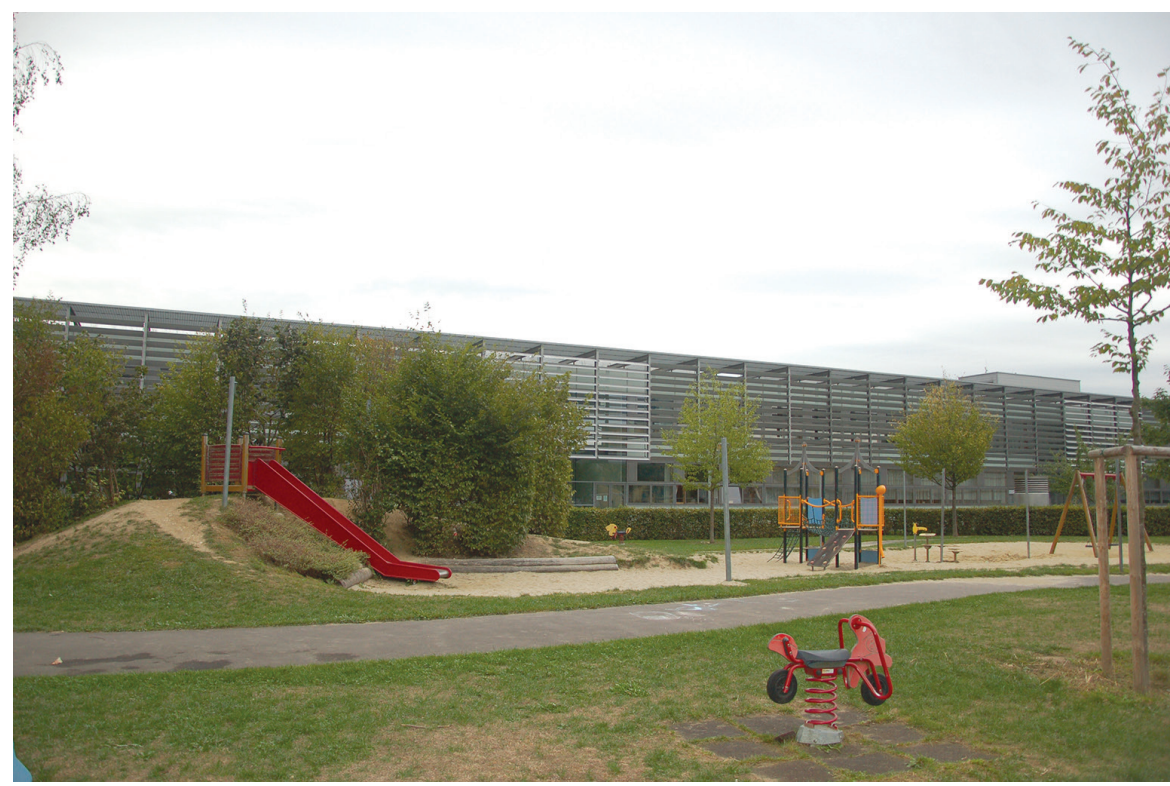

II. 10. Linz, SolarCity, Szkoła BRG SolarCity, tereny rekreacyjne (fot. M. Bednarz) III. 10. Linz, SolarCity, BRG SolarCity School with recreational space 


\section{PRZYPISY}

1 W. Kopaliński, Integracja, [w:] Słownik wyrazów obcych i obcojęzycznych, Państwowe Wydawnictwo „Wiedza Powszechna”, Warszawa 1989, s. 232.

2 M. Barry, Nie ma gotowych recept na miasto - O to, jak postrzega miasto, pytamy Martina Barryego [WYWIAD], Rozmawiała: Jęksa Agnieszka, 19 wrzesień 2015, http://www.bryla.pl/ bryla/1,90857,18863711,nie-ma-gotowych-recept-na-miasto-o-tym-jak-postrzega-miasto. html (dostęp: 19.03.2017).

3 J. Sepioł, Przestrzeń życia Polaków, http://www.sarp.org.pl/pliki/1908_53fdc64bb3140-pzp_spistresci_1.pdf (dostęp: 24.05.2017).

4 W. Froster, Housing in Vienna. Innovative, social and ecological, Architekturcentrum Wien, Wiedeń 2008, s. 12.

5 Plan Rozwoju Obszarów Miejskich - niem. Stadtentwicklungsplan (STEP), jest instrumentem ogólnego i perspektywicznego planowania i rozwoju obszarów miejskich. Zachęca do zrównoważonego kształtowania miasta w zakresie ogólnym: określa obszary rozwijające się, dominującej zieleni i otwartych przestrzeni, jak również przewiduje rozbudowę infrastruktury transportowej (metro, pociąg, tramwaj oraz sieć drogowa realizowane na wysokim poziomie). Wskazuje on przestrzenne i funkcjonalne relacje pomiędzy miastem i regionem. Podstawą do kontynuacji planu zagospodarowania przestrzennego są wyniki badań i ekspertyz, jak również monitorowanie rozwoju mieszkalnictwa. Plan Rozwoju Obszarów Miejskich stanowi zatem wytyczną dla tych w administracji, którzy są odpowiedzialni za szczegółowe planowanie i wyznaczanie priorytetów finansowych na rozwój infrastruktury.

6 A. Włoch-Szymla, Kształtowanie się przestrzeni miejskiej w środowisku zamieszkania Wiedeń, „Czasopismo Techniczne”, 3-A/2010, s. 303.

7 M. Kozień-Woźniak, Dzieło architektoniczne w przestrzeni ludycznej, „Czasopismo Techniczne", 6-A/2008, s. 386-89.

8 W. Froster, op. cit., s. 66.

9 projektu CoopHimmelb(I)au (przypis autora).

${ }_{10}$ W. Froster, op. cit., s. 68.

${ }^{11}$ A. Drapella-Hermansdorfer, Gazometry Simmering - miasto z recyklingu w mieście XXI wieku, [w:] XII Seminarium z cyklu: „Krajobrazy XXI wieku: idee, strategie, realizacje” Austria, Włochy 12-18/19 września 2015, Raport serii SPR nr W1A/S-013/15, Wydział Architektury, Politechnika Wrocławska, Wrocław 2015.

12 Ibidem.

${ }^{13}$ A. Wimmer, Projekte/Wohnen Villa Verdi, http://www.awimmer.at/jart/prj3/wimmer/main.jart?rel=de\&reserve-mode=active\&content-id=1164397024789\&projekte_ $\mathrm{id}=1164397025624$ (dostęp: 21.01.2017). 
${ }^{14}$ B. Wojtyszyn, Ekologiczna realizacja miasta „SolarCity" inwestycja w przyszłość zrównoważonego rozwoju obszarów miejskich w Austrii, „Zeszyty Naukowe. Inżynieria Środowiska/ Uniwersytet Zielonogórski", Nr 160 (40)/2015, s. 29.

15 S. Wehle-Strzelecka, Architektura mieszkaniowa otwarta na przyrodę-przykłady austriackie, „Czasopismo Techniczne”, 3-A/2014, s. 156.

${ }^{16}$ B. Wojtyszyn, op. cit., s. 30.

17 Ibidem; Ekologiczna realizacja miasta - „SolarCity” Linz-Pichling, Inwestycja w przyszłość zrównoważonego rozwoju obszarów miejskich, [w:] XII Seminarium z cyklu..., op. cit.

${ }_{18}$ M. Walków, SolarCity Linz - Pichling, http://uslugiekosystemow.pl/?q=node/183 (dostęp: 17.01.2017).

19 LINZ LIFE, SolarCity Pischling Evaluation, http://www.linz.at/english/life/3203.asp (dostęp: 19.03.2017).

${ }^{20}$ B. Wojtyszyn, op. cit., s. 32.

${ }^{21}$ Ibidem; Ekologiczna realizacja miasta - „SolarCity” Linz-Pichling..., op. cit.

22 Obecna nazwa to Rambol Studio Dreiseitl, pracownia jest częścią Ramboll Group, [Rambol Studio Dreiseitl, http://www.dreiseitl.com/en/start (dostęp: 24.05.2017)].

${ }^{23}$ Ramboll Group, SolarCity, http://www.ramboll.com/projects/germany/solar-city (dostęp: 20.03.2017).

${ }^{24}$ G. Schneider-Skalska, Zrównoważone środowisko mieszkaniowe; społeczne - oszczędne piękne, Wydawnictwo PK, Kraków 2012.

25 J. Sepioł, Przestrzeń życia Polaków, http://www.sarp.org.pl/pliki/1908_53fdc64bb3140-pzp_spistresci_1.pdf (dostęp: 24.05.2017).

\section{BIBLIOGRAFIA}

Barry M., Nie ma gotowych recept na miasto - O to, jak postrzega miasto, pytamy Martina Barryego [WYWIAD], Rozmawiała: Jęksa Agnieszka, 19 wrzesień 2015, http://www.bryla. pl/bryla/1,90857,18863711,nie-ma-gotowych-recept-na-miasto-o-tym-jak-postrzega-miasto.html (dostęp: 19.03.2017).

Drapella-Hermansdorfer A., Gazometry Simmering - miasto z recyklingu w mieście XXI wieku, [w:] XII Seminarium z cyklu: „Krajobrazy XXI wieku: idee, strategie, realizacje” Austria, Włochy 12-18/19 września 2015, Raport serii SPR nr W1A/S-013/15, Wydział Architektury, Politechnika Wrocławska, Wrocław 2015.

Froster W., Housing in Vienna. Innovative, social and ecological, Architekturcentrum Wien, Wiedeń 2008.

Kopaliński W., Integracja, [w:] Słownik wyrazów obcych i obcojęzycznych, Państwowe Wydawnictwo „Wiedza Powszechna”, Warszawa 1989, s. 232. 
Kozień-Woźniak M., Dzieło architektoniczne w przestrzeni ludycznej, „Czasopismo Techniczne”, 6-A/2008, s. 386-89.

LINZ LIFE, SolarCity Pischling Evaluation, http://www.linz.at/english/life/3203.asp (dostęp: 19.03.2017).

Ramboll Group, SolarCity, http://www.ramboll.com/projects/germany/solar-city (dostęp: 20.03.2017).

Schneider-Skalska G., Zrównoważone środowisko mieszkaniowe; społeczne - oszczędne piękne, Wydawnictwo PK, Kraków 2012.

Sepioł J., Przestrzeń życia Polaków, http://www.sarp.org.pl/pliki/1908_53fdc64bb3140-pzp_ spistresci_1.pdf (dostęp: 24.05.2017).

Walków M., SolarCity Linz - Pichling, http://uslugiekosystemow.pl/?q=node/183 (dostęp: 17.01.2017).

Wehle-Strzelecka S., Architektura mieszkaniowa otwarta na przyrodę - przykłady austriackie, "Czasopismo Techniczne”, 3-A /2014, s. 147-60.

Wimmer A., Projekte/Wohnen Villa Verdi, http://www.awimmer.at/jart/prj3/wimmer/ main.jart?rel=de\&reserve-mode=active \&content-id=1164397024789\&projekte_ id=1164397025624 (dostęp: 21.01.2017).

Włoch-Szymla A., Kształtowanie się przestrzeni miejskiej w środowisku zamieszkania - Wiedeń, „Czasopismo Techniczne", 3-A/2010, s. 301-309.

Wojtyszyn B., Ekologiczna realizacja miasta „SolarCity” inwestycja w przyszłość zrównoważonego rozwoju obszarów miejskich w Austrii, „Zeszyty Naukowe. Inżynieria Środowiska /Uniwersytet Zielonogórski", Nr 160 (40)/2015, s. 28-37.

Ekologiczna realizacja miasta - „SolarCity” Linz-Pichling, Inwestycja w przyszłość zrównoważonego rozwoju obszarów miejskich, [w:] XII Seminarium z cyklu: „Krajobrazy XXI wieku: idee, strategie, realizacje” Austria, Włochy 12-18/19 września 2015, Raport serii SPR Nr W1A/S-013/15, Wydział Architektury, Politechnika Wrocławska, Wrocław 2015. 